- Made Gede Windu Saskara

\title{
Chinese Youth Culture Reflective Experience and Challenges for Bonus Demographic in Indonesia
}

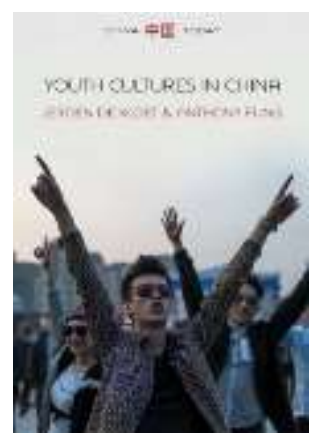

Title

: Youth Cultures in China

Authors

: Jeroen de Kloet, Anthony Y. H. Fung

Publisher

: John Wiley \& Sons/Polity

Year

: 2016

ISBN

: 9780745679174

Length

: 240 pages

\section{By: Made Gede Windu Saskara}

$\mathrm{S}$ ocial changes are an inevitable situation in history and it relates to some concepts of continuity, renewal or evolution just like a living creature that live, grow and die in the end. Changes in this context should be described in synchronic space aspect, longed in time or diachronic (Kartodirdjo, 1992: 121).

Based on the situation, the book elaborates implication of social changes in China after Mao Tse Tung totalitarian era (1976) until the end of Open Door Policy issued by Deng Xiao Ping (1978) where China started to open itself to Western influence to modernize China through science and technology. It flourished social and economic life in Chine aside the State control of The Chinese Communist Party as the single ruling party in the State.

Youth is another key subject in the research, as youth has historical meaning with constant meaning redefinition throughout the time. Years before, Chinese youth is defined through revolutionary spirit against imperialism in the 20th century. The meaning of Chinese youth, after the Open Door Policy, is no longer

related to ideological and political revolutionary issue. Not just issue of socialism, communist or democracy adopted by Western, the issue of Chinese youth after the Open Door Policy is about the influence power from abroad: globalization related to technology and internet. The impact is on the borderless geographical site and culture. Manual Castells stated the situation as fluid and flowing time and space (Castells, 2010). Time and space are without distance because it is connected with many networks in the world. Information flows easily through private and public areas in China, with consent on powerful State censorship 
on the content. The research also described what actually happens in China now, which encourages one sociological question about this book. What is the role and position of Chinese youth in the middle of "war" between world globalization and contradictive Chine political and economic policy? China has turned into an authoritarian, communist and socialist country but also implemented western capitalism after 1980s. The research was started in 1990s, although the focus was on Youth during era between 2005 and 2015.

\section{Cultural Landscape of Chinese Youth 1990 - 2016}

Globalization is the theoretical and practical concept, which in reality has undergone since imperialism and colonialism ended in the mid of 20th century in many countries of Asia and Africa. After that until 21st century, globalization flows fluidly with soft power. The impact of the reality is in form of pop culture or global pop culture where capitalism mutated into new form.

Based on the situation, relation between global cultures, especially in pop culture among Chinese youth appeared in some critical issues such as: authenticity and glocalization, social class representation in center-periphery frame, mobility and virtual room; last but not least is heterenormativity and alternative culture one another that will be described in next chapter.

\section{Authenticity and Glocalization}

In China, theoretical debates on cultural globalization are based on authenticity issues as aspect of geopolitical representation (note: it is the same with debate issue of Indonesia batik claimed by Malaysia). It also relates to problem of Western versus China orientalism where China is a country implementing contradictive double standard. Although
China implemented Open Door policy, the state controls the policy for the sake of State's interest. The impact is on state role to implement supervision through censorship on media or other influences against state instability.

In the mid-1980s, the presence of western pop culture in China, especially rock music, is adopted by underground music scene in China. Rock music is manufactured in the West (USA) and many Chinese youth loved rock music. However, they did not adopt or imitate rock music just the way it is. Chinese rock band in China adopted rock music in China style or with China characteristic. Rock music turned into "Chinese rock music" or "Chinese sound" with "Western Rock". It is the form of hybrid or cross culture (Bhaba, 1994). Although they played rock music using western instrument (electric guitar, bass, drum, amplifier) they played rock music with Chinese identity, from lyric, tones, melody and often put Chinese tradition music elements as part of Chinese identity.

This also indicated that Chinese youth still have mindset or thinking pattern that China has great ancient civilization. Therefore, culture globalization, especially western, should be adopted with Chinese spirit. The purpose is clear that Chinese identity and character should be appear Chinese glocalization also runs in production of culture and media such as $\mathrm{TV}$, movies and fashion.

Related to the term, in 1990s, media in China is usually under strict supervision by State, so the acceleration of cultural information through media is slow. Changes are shown in year 2001 when China became member of World Trade Organization (WTO). There are duplicated foreign TV shows in local TV shows. The show is reproduced with Chinese characteristic, although sometimes ignoring copyright and showing right of the original producer. Pragmatically, local TV stations produced and exploited many foreign TV shows for profit. 
Glocalization in form of duplication and adaptation is normal act in media industry. Some TV programs in China are duplication or adaptation from outside, such as Meteor Garden (teenage TV drama). The movie itself was originated from Japan's comic Boys of Flowers, and then adapted by Taiwanese TV producer into Meteor Garden TV drama (CTS, 2001). The success of the TV serial drama spread to East Asia and South East Asia including Indonesia. In China, the drama was duplicated and adapted into a TV drama entitled Let's Go Watch the Meteor Show (broadcasted by Hunan TV between 2009 and 2010) and became teenage hit TV drama with high rating. The TV drama has made significant profits for the station.

The film was considered success as the state supported the content of the movie that has been adapted to Chinese Confucianism values. The state did not put censorship and interference on the movie. The movie, combination of fictional story and teenage romantic, showed youth as a generation that should work hard to pass many tests in life such as school test until test of life to build career and achieve the dream.

Another case is TV drama Super Girl (Hunan TV, 2005), a singing contest TV Show adopting Pop Idol format (ITV, England) and American Idol (Fox Network, USA). State interfered and banned the show based on reason of Western democracy and freedom influence in the content of the show, where a contestant will be eliminated in each episode based on voting process through $S M S$.

For the record, in media such as TV and movie, the production of media content should be based on State interest and party ideals in order to gain approval. State conducted social control but not involved in production process. It was the concern of the media producer.The minimum role of state in media production was also affected by specific situation in industry and market, where pragmatism in commercial is the main issue to boost State economy.

In year 2000, along with growing economic in East Asia after 1980s, there was a raise of Eastern Asia pop culture such as Korean,K-Pop or Japanese,J-Pop, in almost all Asian countries. It shows that global pop culture is no longer a centralized western product.

There are many competitions on alternative shows as part of new mode of consumption among youth worldwide. In China, there are some singing groups formed to adopt the new growing pop culture such as $\mathrm{SNH} 48$, a singing group consist of 12 female teens aged 20 years old from Shanghai, adopting $A K B 48$ concept (Tokyo, Japan). It was then followed by China teenage boyband named TFBoys (The Fighting Boys). The duplication of concept showed significant economic income in entertainment industry, especially on teenage market segment. The duplication and adaptation are clearly not related to the concept of interstate politic, as it is just duplication and adaptation of pop culture.

Based on its situation, entertainment media industry in China also affected the global and regional pop culture. The content was adapted, spread, internalized and consumed by Chinese youth. The media played key role in shaping the youth culture. Sociologically, the glocalization is a strategy, terms or adapting, although it was one form of hybrid, modification and resistance in alternative market positioning.

There is a unique gradation in China, in a different perspective, where they hit the boundary of authenticity through "piracy" and copying global product. One example was "Shanzai Style" or "Shanzai Culture" in Shenzen area where you can find knocks off fashions using well-known brand in the world with affordable price. It shows paradox and contradiction in China where glocalization is not just about culture modification related to "China" but also about economic motives. The "Shanzai 
Style" definitely targeted youth as potential exploited market where "Shanzai style" provide trendy and fashionable style with affordable price.

\section{Social Class, Generation Gap, Mobility and Virtual Space}

Related to previous description, in term of youth culture, Chinese youth fashion style should be viewed on the relation of political-ideological identity, economy and creativity. Bourdie (1984) stated that fashion style is also part of "difference" representing the different taste and social status where both are determined through capital of culture, social and economy.

High and middle class economic youth in cities choose to buy clothes at the modern and branded fashion retail while some urban youth on peripheral areas prefer fashion with affordable price, despite the reality that they are knockoff products. However, in other gradation, there is potential of subjective pragmatism motives among those social classes in China. In his field observation, De Kloet watched punk music concert in China and found a fan wearing red scarf and t-shirt written "Communist League Youth". In major cities, wearing that kind of shirt is considered as political statement and ideology adopted in Mao era. However, fashion style is not merely identical to political statement as currently there are more pragmatically youth in China where they prefer affordable price style to look trendy and also for mix and match.

Based on situation above, the class difference, taste and motive on one side also implied to generation gap or point of view among generation. An example was "rolled stocking" or "under thigh stocking" which was a trendsetter among women in China during 1980s and 1990s. For some old generation people the style introduced "vulgar" style among teen where it never happened before. They considered the style as deviation or even violation on traditional values that may affect to morality.

On the other side, youth considered the style was not offensive but only as selfexpression in sense of fashion and creativity, it was about how they modified fashion style through mix and match method.

Still in social class context, on other example, some children from high and middle class society was sent to school abroad and returned to continue their parents business, middle class youth studied hard to get jobs as white collar labor while urban youth on peripheral areas tried to survive by migration to industrial area. They worked as labor in factories.

Labor or "dagong" in China is considered as low social class in China that burden negative stigma due to Mao historical policy. In general, Chinese youth expected a better future and working as dagong is not part of their dream.

Ironically, State and corporation stated proudly that the increasing national economic growth was part of labor's contribution. State and corporation use hegemony to control mental condition of labor in order to encourage labors for national economic and prosperity. It was a contrary when labor was paid so low with polluted and unhealthy working environment (Middler, 2009). Labors were exploited, alienated from their environment and socially marginalized. Furthermore, Midler also stated that manufactured items in China have dubious quality, or known in Indonesia as "carelessly manufactured product (produk abal-abal)."

Based on another narration, the high load work opened new opportunity in social and economic expression. Many migrant youth spend more leisure time on virtual reality in internet. They rent internet use in internet cafe (Warnet in Indonesia term), because they could not use gadgets and internet in their factory.

Internet is new form of technology creating a virtual world and it becomes 
catharsis of life, digital aspiration space for opinion, expression, personal experiences, satire story, and life. Many of them documented their pictures and articles about life in blogs. Some of them gained great attention as they are based on reality with high emotional scale which in turn increases internet traffic to web page or page view.

Not only web blog, some migrant youth also spend their leisure time by chatting and playing online games. In this virtual space, they played in multiple identities between social reality (offline) and virtual reality (online). Chatting is room for youth to hold conversation with their friends from same village, information on work opportunity, love, and others. Online games on the other side are not just to spend leisure time, but also to gain more income. Many youth became gamers and employed by owner of internet cafe to gain income. They became new generation of "gold farming" where they can get virtual money through "gold coins" in online games. The virtual money can be converted into real money in the millennial era. The term also expands the meaning that differ it with "traditional farming" where peasants work on their field. youth in China consider farming is no longer working on field but playing with joy in virtual world.

\section{Heterenormativity and Alternative Culture}

Economic growth, improved life condition and education, has raised new pattern of thinking among youth in China. Many youth who returned from their education abroad entered new standard of rich people and adopted western culture. New perspectives are growing and being implemented, especially in cities.

Western global culture on one side also encourages awareness on personal freedom. Subjectivity and sexuality are central issue spoken out by many youth. De Kloet said it is a form of heteronormativity, a new diversity of norms living among steady and implemented norms.

Some youth in cities discussed sex and health issues in open, not only in domestic area. Sexuality has become public issue, where it transformed reproduction process into recreation process. Sex has become semi-permissive concept among youth in cities. They conducted sexual activities such as kissing and intercourse before they got married. There is pragmatically perspective on how to enjoy safe and healthy sex by using contraceptions. The option is also conducted to ensure that the partner is the right choice for long term relation.

Their open thoughts to diversity situation also encouraged new perspective on gender and different sexual preferences. Global movement in feminism and LGBT grew in some cities in China despite its low supporters.

Based on the situation, heterenormativity did not represent whole attitude of youth in China and not related to resistance against steady and implemented traditions. Heterenormativity is considered as alternative culture, a sub culture condition growing side by side by general norms. In reality, there are many conformist youth holding Confucianism values and State ideology. It shows the relation between state, educational institution and family is still strong in community.

\section{China Experiences and Challenges for Demographic Bonus in Indonesia}

China is one of the most populated countries in the world, around 1,3 billion people (Wikipedia, 2017) and became main power to run economy in China. There is a joke, saying in the internet that, "Earth and everything lives in it is made by God, the rest is made in China". It became empirical picture on the fact that China has strong global influence for its population and how the population is optimized and productive. In industry context, the power of China 
population can be seen on the spread of China's made products worldwide. The factor is also supported by the varied home industry in China. There are also many transnational companies moved their factories to Chine due to its low production cost.

China, in post Open Door Policy era, has shown its ability to challenge democratic countries where they can advance without the ideas of Western individual freedom, democracy, capitalism in global world. China is confident to stay with the Socialism-Communism ideology with its contradictive theories to the State capitalism economy. Although contradictingly, their economy is now aimed at capitalism. It is an interesting point to be discussed on how China defines the ideal and unique characteristic.

Based on the situation, youth is the most population absorbed in economic sector, from home industry to digital world. China has built industries to develop China's social and economic condition. They are asset and also tools to develop the nation in current jargon of "China Dreams".

Speaking of youth in China is related to the power relation of State, educational institution and family. It is about how youth is positioned in the society. On the other side, youth has own subjective space and defined as youth culture. It is also related to the global culture context where pop culture is adapted through reproduction of media and technology development such as internet that grew rapidly after year 2000 and supported the identification process.

\footnotetext{
${ }^{6}$ Alibaba is a Chinese e-commerce conglomerate that provides consumer-to-consumer, business-toconsumer and business-to-business sales services via web portals. It also provides electronic payment services, a shopping search engine and data-centric cloud computing services. The group began in 1999 when Jack Ma founded the website Alibaba.com, a business-to-business portal to connect Chinese manufacturers with overseas buyers (Wikipedia, 2017).
}

Youth has subjective autonomous personal space, where creativity, talent, strategy and energy were transformed into productivity. The example of this concept is digital technology companies, such as "Ali Baba" (Jack Ma) ${ }^{6}$ and "Tencent" (Ma Huateng, Zhang Zhidong, Xu Chenye, Chen Yidandan Zeng Liqing) ${ }^{7}$ that have become worldwide focus.

Based on the situation, one important issue on social changes in every era is on the role of youth as key factor that developed social structure. In this context, especially on the internet technology, the global landscape moved to digital convergence where various media technology are integrated and connected through network and encouraged more changes in communication model that changed the economic structure. The world moved fast into new line of business, the digital economy through technopreneurship and Startup Company controlled by youth.

Aside of negative image of China's products over quality, knockoff, piracy, and powerful China Communist Party in censorship, Indonesia should take positive side on comparative study on China over how to take advantage of population bonus to run the State economy. Indonesia is the 4th most populated country with more than 255 million people after India, China and USA (Wikipedia, 2017). The population should be key resource for Indonesia as in 2020 - 2030 Indonesia will have demographic bonus on the raise of people in productive age $(15-64$ years old) up to $70 \%$ (Suara Indonesia untuk Perubahan, 2016). The youth in this concept is group

\footnotetext{
7"Tencent" is a China company focusing on internet products such as social network and message services. Tencent is key player in Chinese social media for WeChat, Moments, Mobile $Q Q$ and $Q Q$. The advantage of "Tencent" is supported by government policy that prohibited global social media such as Twitter and Facebook in China. So, 1,3 billion people in China are potential user of their platform (GGWP.ID.2017).
} 
that should be optimized for State ideals for social welfare. Based on the situation, digital revolution after year 2000 brought significant changes in global context, including in Indonesia.

Based on survey conducted by Network Provider Association in Indonesia (APJI), 132 million out of 255 million population in Indonesia are connected to internet while $65 \%$ of Indonesia's population lived in Java (APJI, 2016). Nielsen Indonesia also reported that internet growth in Indonesia increase rapidly from $22 \%$ in 2012 into $44 \%$ in July 2017. Most internet users are teenagers aged $16-24$ years old (45\%) followed by people aged $25-34$ years old $(31 \%), 35-$ 44 years old people $(17 \%)$ and finally more than 45 years old (7\%). For entertainment content, YouTube is the most accessed media streaming platform with $98 \%$ portion compared with other platforms (Nielsen, 2017).

These statistics are also empirically supported by the fact that in Indonesia today access to a variety of digital devices (smartphones, tablet PCs, laptops, DSLR cameras) are increasing and easily obtainable at relatively affordable prices. The situation is different compare to the 1990s where the devices are considered luxurious items.

Telecommunication infrastructures also grew and improved to ease information access. Many people in countryside have digital devices, even though internet access is better in cities.

Some youth in major cities in Indonesia, after year 2009, has responded the growing internet by developing start up business in information technology. They were called technopreneur or digitalpreneur. Some well-known people

\footnotetext{
8"Tokopedia" and "Bukalapak" are digital trading platform in form of online web working as legal online intermediary between sellers and consumers. Every person, shop or even small entrepreneur is allowed to sell their products online just by free registration and verification. "Gojek", is a digital
}

are William Tanuwijaya (Tokopedia). Achmad Zaky (Bukalapak) and Nadiem Makariem (Gojek). ${ }^{8}$

"Tokopedia", "Bukalapak", "Gojek" are current form of business landscapes, how Indonesian youth who was born in 1980s adapted technology and challenges steady world business. They shifted paradigm where successful business need years of process. The use of information technology, capturing market potential and some digital financial resources (home and abroad) the youth only need less than ten years to grow their internet business.

Not only based on legal institution, the movement of Indonesian youth currently is also in the solitary space. The pattern is random but massive. They grew internet content production in form of articles, product review and multimedia services (audio, animation, graphic design, video) in many online marketplaces.

Currently, there are many Indonesia youth producing video content and they uploaded it in video streaming services such as YouTube. They are now called YouTuber. The video usually displayed reality of Indonesian youth in millennial age, such as daily activity, informal interviews, comedy, music, daily life tips, product review, games, etc. Some of them are famous because they have more than a million subscribers. Some of them are: Raditya Dika, Edho Zell, Reza Oktovian, Tim2one-Chandra Liow, Ricis official, Bayu Skak, SkinnyIndonesian24, etc (Detikinet; 2017). From Youtube, their income can reach tens of millions of rupiah per month based on commercial and AdSense in Youtube (Kompas.com; 2017).

These youth has broken the old saying where they must work at the office or become civil service to gain better

company running as intermediary for transportation needs between ojek (motorcycle taxi) and consumers. Not only transporting people, Gojek also developed platform for Go-Car, Go-Food, Go-Mart, Go-Send and others. The services are available on major cities in Indonesia. 
income. They simply just played with their creativity and gained much deserved income.

Based on the situation, youth culture is colored with creativity as basis to see potential of creative economy to support the demographic bonus. The demographic bonus should provide productivity and encourage economic growth through development of human capital, because youth is in the productive age with strong bound to creativity and technology. Youth will always generate creative and fresh ideas underlining creative economy as the source that always require renewal ideas. It is different to natural resources that will be depleted slowly.

Youth, as the highest part of the population, is no longer considered as consumer but also producer. Therefore, the challenge for continuous development of youth by the government is: 1) to create conducive ecosystem with supply, development and advancing telecommunication infrastructure in all Indonesia regions. 2) Develop, guide and facilitate youth in productive age to increase their creative ideas in producing positive works in the society. The implementation is through creative education and vocational education or skill improvement (training, workshop and certification) about creative world, financing, creativity room, business incubator supporting the development of qualified entrepreneur through commercial and constructive activity, especially for youth. 3) Synergy among youth as power of creative economy to strengthen Indonesia identity as brand or identity to lift and optimize local content full of cultural heritage.

All three points above are very important in developing demographic bonus in Indonesia where the main goal is to increase Indonesia economic in the future. Youth is the key for the next leader of the nation, despite a question about demographic bonus, is it a productive advantage or not? China now has shown their ability to become key player in global economy by taking advantage of youth population. Indonesia should have the same ability to develop youth. Hopefully!

$$
* * *
$$

As a contemporary research, the book gives great contribution on study of youth in China based on sociological, anthropological and social history approaches. How the youth China landscape is framed in relation between State, School and Family. How youth responded changes from abroad through technology, media and global culture and adapted them subjectively based on their time. In this case, China cannot be described as an absolute entity because there are many contradiction, dynamic and negotiation. It could be comparative study to see global youth culture, how globalization worked and became dialogue in local sphere with varied experiences.

$* * *$

\section{References:}

Asosiasi Penyelenggara Jasa Internet Indonesia \& Polling Indonesia. 2016. Infografis: Penetrasi \& Perilaku Pengguna Internet Indonesia. Jakarta.

Aulia, Luki. 2017. "Memburu Impian Baru di Era Baru", Kompas, 28 Oktober, p. 3

Bhaba, Homi. K. 1994. The Location of Culture. London, New York: Routledge.

Bohang, Fatimah Kartini. "Punya 1 Juta Subscriber, Berapa Pendapatan YouTuber Bayu Skak?". Kompas.Com. 18 September 2017. Retrieved November 1, 2017. (http://tekno.kompas.com/read/2017/09/ 18/15463987/punya-1-juta-subscriberberapa-pendapatan-youtuber-bayu-skak)

Bohang, Fatimah Kartini. "Ini Dia, Enam YouTuber Indonesia yang Punya 1 Juta Subscriber." Kompas.Com. 19 
September 2017. Retrieved November 1 ,

2017.(http://tekno.kompas.com/read/20 17/09/19/15440027/ini-dia-enamyoutuber-indonesia-yang-punya-1-jutasubscriber?page $=$ all)

Bourdieu,. Pierre 1984. Distinction: A Social Critique of the Judgement of Taste. USA: Routledge \& Kegan.

Castells, Manuel. 2010. The Rise of the Network Society.(2nd Edition). UK: Blackwell Publishing.

Kartodirdjo, Sartono. 1992. Pendekatan Ilmu Sosial dalam Metodologi Sejarah. Jakarta: Gramedia.

Midler, Paul. 2009. Poorly Made in China: an Insider's Account of the Tactis Behind China`s Production Game. USA: Willey \& Sons

Nielsen Indonesia. 2017. The New Trend Among Indonesia's Netizens: How and where Digital Consumers are Watching Content Online. Indonesia: Jakarta.

Prasetyo, Audi Eka. 2017. "6 Fakta Tentang Tencent dan Kerajaan Game yang Mereka Miliki di Dunia!". GGWP.ID. 11 Juli 2017. Retrieved November 1, 2017.

(https://ggwp.id/2017/07/11/faktatencent-game/ )

Rachmatunnisa. 2017. "10 YouTuber Indonesia dengan Subscriber Terbanyak". Detikinet. 11 Juli 2017. Retrieved November 1, 2017. (https://inet.detik.com/cyberlife/d3555829/10-youtuber-indonesiadengan-subscriber-terbanyak)

Setiawan, Sakina Rakhma Diah. 2017. "GoJek Dapat Suntikan Modal dari Raksasa Teknologi China Tencent".

Kompas.Com. 5 Juli 2017. Retrieved November 1, 2017. (http://ekonomi.kompas.com/read/2017/ 07/05/123000326/gojek.dapat.suntikan. modal.dari.raksasa.teknologi.china.tence nt)

Utami, Restu. 2016. "Bonus Demografi dan Kesempatan Ekonomi Kreatif”. Suara Indonesia Untuk Perubahan. 3 November 2016. Retrieved November $1,2017$. (http://www.siperubahan.com/read/ekon omi/1481861944/bonus-demografi-dankesempatan-ekonomi-kreatif)

Wikipedia.2017. "Daftar Negara Menurut Jumlah Penduduk." Retrieved November 1, 2017. (https://id.wikipedia.org/wiki/Daftar_ne gara_menurut_jumlah_penduduk).

Wikipedia.2017. "Jack Ma". Retrieved November 1, 2017. (https://en.wikipedia.org/wiki/Jack_M a)

Wikipedia.2017. "Tencent". Retrieved November 1, 2017. (https://en.wikipedia.org/wiki/Tencent) 